\title{
EARLY WARNING OF RAINFALL-INDUCED LANDSLIDES AND DEBRIS FLOWS ON MT. BAWAKARAENG, SOUTH SULAWESI, INDONESIA
}

\author{
Hasnawir $^{1}$ \\ Received : 22 June 2012, Accepted : 21 May 2013
}

\begin{abstract}
Rainfall thresholds that form the basis of the landslide warning systems now exist for a few areas in Indonesia. Based on analysis of historical data, threshold performance varies according to precipitation characteristics, and threshold exceed corresponds to a given probability of landslide occurrence. Early warnings of landslides and debris flows that include specific information about affected areas, probability of landslide and debris flow occurrence, and expected timing are technically feasible as illustrated by a case study made on Mt. Bawakaraeng, South Sulawesi, Indonesia. Records from 1997 to 2007 of rainfall data and history of landslides and debris flows were collected from the Ministry of Public Works of the government of Indonesia. The threshold, as defined by the lower boundary of the points representing landslides and debris-triggering rainfall events, is expressed by the equations $I=41.85 D^{-0,85}$ before the large scale landslide on March 26, 2004 and $I=37.71 D^{-0,90}$ after the large scale landslide, where $I$ is the rainfall intensity $(\mathrm{mm} / \mathrm{hr}$ ) and $D$ is the duration of rainfall (hr). According to empirical threshold analysis, the regression curve can be considered as a reliable rainfall intensityduration threshold for the study area, above which, landslide or debris flow event may occur.
\end{abstract}

Keywords: Early warning, landslide and debris flow, rainfall thresholds, Mt. Bawakaraeng

\section{INTRODUCTION}

In recent years landslides and debris flows have caused damage to the natural resources in Indonesia. Losses of lives, destruction of properties, economic losses and adverse impacts to the environment have been caused by these phenomena every year. Particularly in South Sulawesi Province landslides and debris flows have been important issues for mitigation, especially since 2004. A large scale landslide including a debris flow occurred on Mt. Bawakaraeng caldera in year 2004, with a volume of about 232 million $\mathrm{m}^{3}$. The landslide was caused by the collapse of the walls of the caldera resulting in the flow of a large amount of debris with significant damages including 32 deaths and destruction of properties (Tsuchiya et al., 2004).

${ }^{1}$ Forestry Research Institute of Makassar, Ministry of Forestry of Indonesia

Corresponding Author:wirforest@yahoo.com
Moreover, on Mt. Bawakaraeng caldera, the majority of landslides and debris flows have been triggered by intense rainfall (Hasnawir and Kubota, 2009).

Characterization of landslide-triggering rainfall has been used to establish the relation between rainfall and landslides in various parts of the world. The most commonly investigated rainfall parameters in relation to landslide initiation include cumulative rainfall, antecedent rainfall, rainfall intensity, and rainfall duration. Attempts have been made to define thresholds employing various combinations of these parameters. Since the majority of slope failures are triggered by extreme rainfall, a number of researchers (e.g., Campbell, 1975; Cotecchia, 1978; Caine, 1980; Pomeroy, 1984; Cannon and Ellen, 1985; Neary and Swift, 1987; Kim et al., 1991; Wilson et al., 1992; Larsen and Simon, 1993; Wilson and Wieczorek, 1995; Wieczorek, 1996; Terlien, 1998; Crosta, 1998; Crozier, 1999; Glade 
et al., 2000; Wieczorek et al., 2000; Aleotti, 2004; Guzzetti et al., 2004; Hong et al., 2005; Giannecchini, 2006) have attempted to establish rainfall intensity thresholds so that slope failure predictions could be made accurately. These various works define rainfall threshold in terms of rainfall intensity, duration vs. intensity ratio, cumulative rainfall in a given time, antecedent rainfall vs. daily rainfall ratio, event rainfall vs. yearly average rainfall ratio, and daily rainfall vs. antecedent excess rainfall ratio. Caine (1980) was the first to establish worldwide rainfall threshold values for landslides. Similar threshold values have been proposed for California (e.g., Cannon and Ellen, 1985; Wieczorek, 1987; Wieczorek et al., 2000), the Southern European Alps (Cancelli and Nova, 1985; Ceriani et al., 1992), pre-Alpine regions of Northern Italy (Guzzetti et al., 2004), the Piedmont region of Italy (Aleotti, 2004), Korea (Kim et al., 1991), Southern China (Li and Wang, 1992), Japan (Cotecchia, 1978; Yatabe et al., 1986; Yano, 1990; Hiura et al., 2005) and Puerto Rico (Larsen and Simon, 1993). Recently Dahal and Hasegawa (2008) reviewed representative rainfall thresholds for landslides in the Nepali Himalayas.

In order to develop a warning system for landslides and debris flows, an accurate identification of the rainfall condition that triggers landslide and debris flow is needed. Hence the main objectives of the study were to determine empirical rainfall intensity-duration thresholds for landslides and debris flows for Mt. Bawakaraeng caldera of South Sulawesi, Indonesia.

\section{METHODOLOGY}

\section{A. Study Area}

The study area is located in the Mt. Bawakaraeng caldera (Figure 1). The caldera is situated $90 \mathrm{~km}$ from Makassar, South Sulawesi and the elevation of Mt. Bawakaraeng is $2,830 \mathrm{~m}$ above sea level. The foot of the collapsed caldera is the head water of the Jeneberang river which is connected to the Bili-Bili Dam. The dam was constructed for multi-purpose usage such as drinking water reservoir and hydroelectricity for South Sulawesi. The soil types of the study area are andosol. According to FAO (2001), soil types which belong to the andosol group are developed from volcanic materials. Most andosols have excellent internal drainage because of their high porosity and their occurrences are predominantly at high elevations. Specific gravity of the soil is 2.70 , porosity is estimated as $66.7 \%-88.7 \%$. The bulk density of andosols is low, not just in the surface soil where it is typically less than 900 $\mathrm{kg} / \mathrm{m}^{3}$ but values as low as $300 \mathrm{~kg} / \mathrm{m}^{3}$ have been recorded in highly hydrated andosols. The bulk density does not change much over a suction range of $1500 \mathrm{kPa}$ (limited shrink and swell).

In the study area $14 \%$ of the land surface has dense forest cover and over $12 \%$ of the area has deteriorated from dense to semi-dense forest. The study area and the surrounding areas consist of $50 \%$ dry farm land, $40 \%$ grass land and about $10 \%$ partly paddy field. The vegetation of the mountainous area is composed of natural forest and forest plantation dominated by Pinus merkusii. Mountain tops are covered by grass without high trees. The morphology of Mt. Bawakaraeng is characterized by high relief, extreme slopes, high degree of weathering as well as erosion activities such as soil movements and landslides. The basement rocks around Mt. Bawakaraeng area consist of the Tonasa Formation, the Camba Formation, the Baturape-Cindako Volcanic Rocks, extrusive and intrusive rocks and the Lompobattang Volcanic Formation, which were formed from the Paleogene to the Quaternary period (Sukamto and Supriatna, 1982). The geological map and the stratigraphic column of Mt. Bawakaraeng caldera are shown in Figure 2 and Table 1, respectively. The geological units are described as follows (Ministry of Public Works, 2005).

Tonasa Formation: It consists of limestone and marl of Eocene to Middle Miocene age. Layered limestone has folded structure with less than $25^{\circ}$ inclination. Camba Formation: It consists of tuffaceous sandstone, tuff and mudstone and pyroclastic rocks of Late Miocene age. It is widely distributed from Maros district to Jeneponto district, and forms a mountainous area in the middle section of the Jeneberang river. Baturape-Cindako Volcanic Rocks: They were formed by volcanic activity during the Pliocene age. They consist of tuff, lava accompanied by conglomerate and breccia. These rock units are distributed in the vicinity of Mt. Maja in southern 


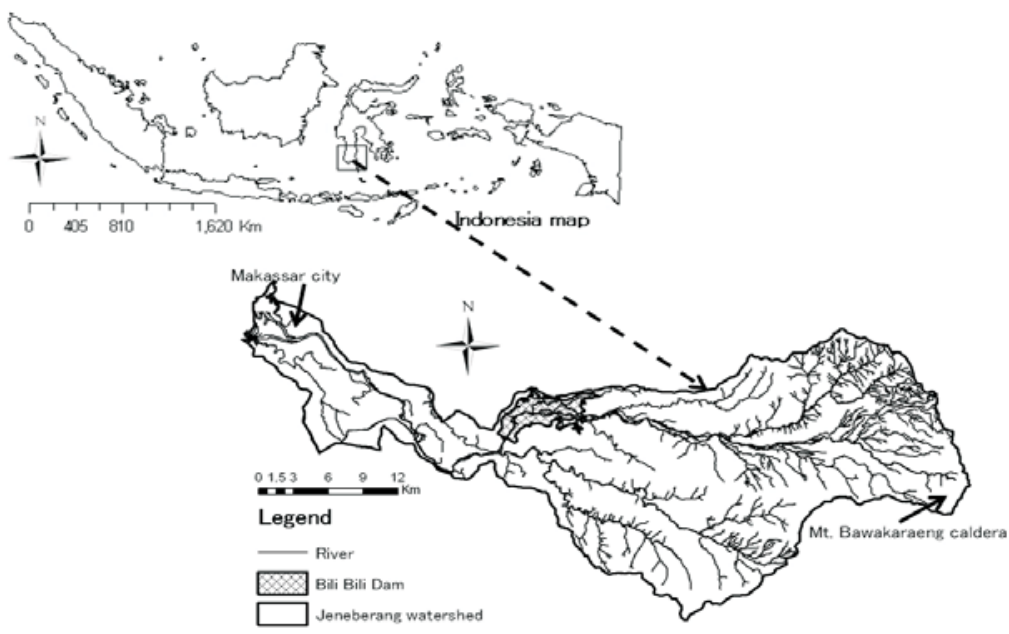

Figure 1. Location map of the study area in Jeneberang watershed, South Sulawesi, Indonesia

Table 1.Columnar section of the geological units around Mt. Bawakaraeng caldera

\begin{tabular}{|c|c|c|c|c|c|}
\hline \multicolumn{2}{|c|}{ Age } & \multicolumn{2}{|c|}{ Formation } & Symbol & Description \\
\hline \multirow{9}{*}{ 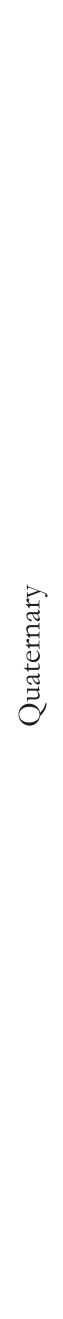 } & \multirow{3}{*}{ 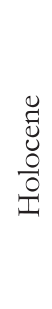 } & \multicolumn{2}{|c|}{$\begin{array}{l}\text { Riverbed } \\
\text { Deposit }\end{array}$} & $\mathrm{rd}$ & $\begin{array}{l}\text { This stratum consists of gravel, sand and clay. The surface of deposit } \\
\text { along the Jeneberang river is covered with debris flow deposit more than } \\
10 \mathrm{~m} \text { in depth at its maximum. }\end{array}$ \\
\hline & & \multicolumn{2}{|c|}{ Talus Deposit-2 } & $\operatorname{td} 2$ & $\begin{array}{l}\text { This stratum consists of fallen rocks, detritus, soil and sand formed by } \\
\text { collapse. Talus deposit formed by the latest caldera wall collapse } \\
\text { accumulated from the hem part of the slope collapse to the downstream } \\
\text { area of Lengkese village along the Jeneberang river. }\end{array}$ \\
\hline & & \multicolumn{2}{|c|}{$\begin{array}{l}\text { Terrace } \\
\text { Deposit-2 }\end{array}$} & $\operatorname{tr} 2$ & $\begin{array}{l}\text { This stratum consists of gravel, sand and clay. Terrace plain has a height } \\
\text { of } 5 \text { to } 20 \mathrm{~m} \text { above the present riverbed. }\end{array}$ \\
\hline & \multirow{6}{*}{ 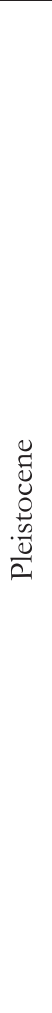 } & \multicolumn{2}{|c|}{$\begin{array}{l}\text { Terrace } \\
\text { Deposit-1 }\end{array}$} & tr1 & $\begin{array}{l}\text { This stratum consists of gravel, sand and clay. Terrace plain has a height } \\
\text { of } 50 \text { to } 75 \mathrm{~m} \text { above the present riverbed. }\end{array}$ \\
\hline & & \multicolumn{2}{|c|}{ Talus Deposit-1 } & $\operatorname{td} 1$ & $\begin{array}{l}\text { This stratum consists of fallen rocks, detritus, soil and sand. This deposit } \\
\text { is widely distributed along ancient Jeneberang river (present Kausisi river), } \\
\text { forming terrace plain with a height of } 50 \text { to } 100 \mathrm{~m} \text { above the present } \\
\text { Jeneberang riverbed. It is deemed that this stratum was formed by debris } \\
\text { flow which occurred in the Pleistocene age. }\end{array}$ \\
\hline & & \multirow{4}{*}{ 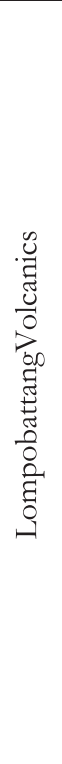 } & $\begin{array}{l}\text { Volcanic } \\
\text { Rocks } \\
\text { Facies-3 }\end{array}$ & Vf3 & $\begin{array}{l}\text { This stratum is distributed at the edge part of the volcano body, and } \\
\text { consists of pyroclastic-sedimentary rocks which are composed of lapilli } \\
\text { tuff, pumice tuff, volcanic breccia and volcanic conglomerate. }\end{array}$ \\
\hline & & & $\begin{array}{l}\text { Volcanic } \\
\text { Rocks } \\
\text { Facies-2 }\end{array}$ & Vf2 & $\begin{array}{l}\text { This stratum is distributed in the whole area of the volcano body, and } \\
\text { forming the alternation of volcanic layer. Volcanic layer consists of } \\
\text { basalt-andesite lava, and pyroclastic rocks which are composed of volcanic } \\
\text { breccia and tuff. In this facies, the amount of lava is superior to that of } \\
\text { pyroclastic rocks. And the continuity of lava is high, and the thickness of } \\
\text { lava is mainly more than } 20 \mathrm{~m} \text {. The rock-mass has columnar joints with } \\
\text { intervals of } 30 \text { to } 200 \mathrm{~cm} \text {, but the hardness of the lava rock is } \\
\text { comparatively high. }\end{array}$ \\
\hline & & & $\begin{array}{l}\text { Volcanic } \\
\text { Rocks } \\
\text { Facies-1 }\end{array}$ & Vf1 & $\begin{array}{l}\text { This stratum is distributed around the vent, and forming the alternation of } \\
\text { volcanic layer. Volcanic layer consists of pyroclastic rocks which are } \\
\text { composed of vent breccia, volcanic breccia and tuff, and lava. But in this } \\
\text { facies, the continuity of lava is low, and the rock-mass like a lens is } \\
\text { formed. Low cementation sedimentary rocks are contained at the } \\
\text { boundary part of the volcanic layers that were formed intermittently. } \\
\text { From these points, the strength of rock -mass is relatively low. }\end{array}$ \\
\hline & & & $\begin{array}{l}\text { Intrusive } \\
\text { Rock }\end{array}$ & Ir & $\begin{array}{l}\text { This stratum consists of dasite that were supplied from magma, and is } \\
\text { distributed as effusive rock and stock around the caldera. Dasite is mainly } \\
\text { composed of Plagioclase, Quartz, and Pyroxene with a diameter of } 1 \text { to } 10 \\
\text { mm, and shows light gray color. The notable feature of dasite is to easily } \\
\text { deteriorate the rock quality by weathering. }\end{array}$ \\
\hline
\end{tabular}

Source: Ministry of Public Works, 2005 


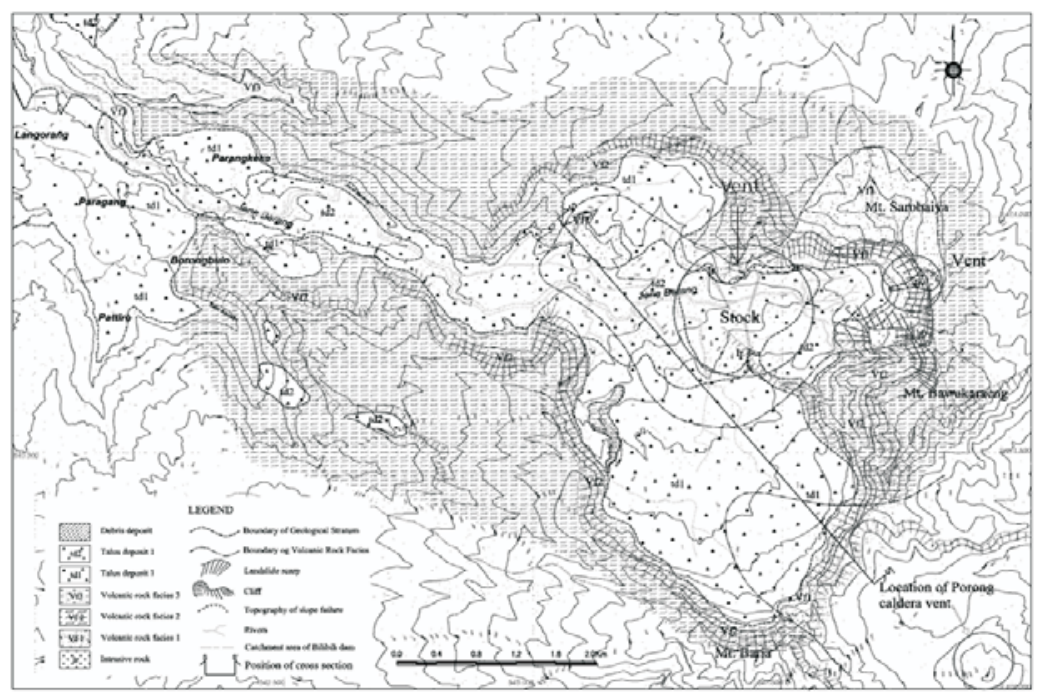

Figure 2. Detailed geological map of Mt. Bawakaraeng caldera Source: Ministry of Public Works (2005)

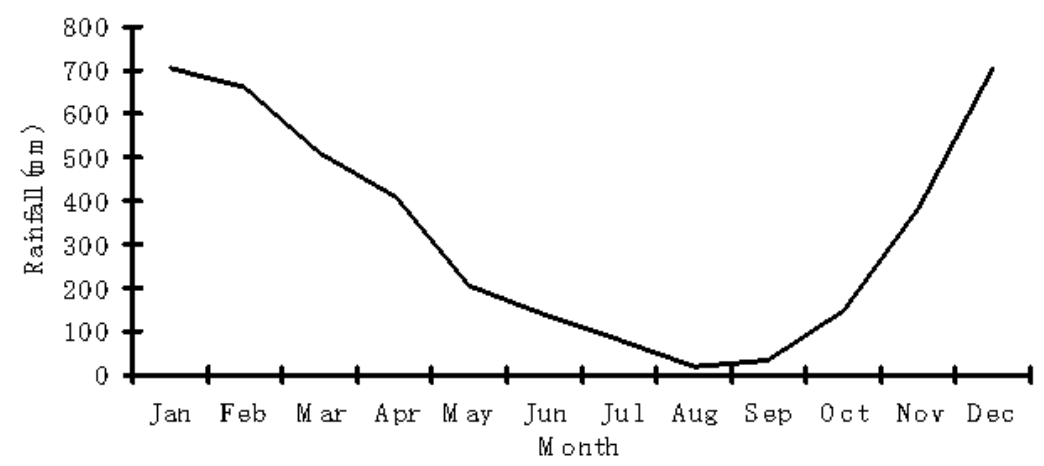

Figure 3. Average monthly rainfall at the study area Source: Analysed data

part of Gowa and in the vicinity of the right tributary of the Jeneberang river.

Extrusive and Intrusive Rocks: Basalt, andesite and diorites of Late Miocene to Pliocene age are distributed as dike, sill and stock rock. They crop out as small rock bodies associated with sedimentary and volcanic rocks. They are distributed in Maros and Jeneponto districts. Lompobattang Volcanic Formation: It consists of andesitic volcanic rocks of Pleistocene age with lava, pyroclastic rocks and secondary deposit. The central portion of Porong Caldera (Figure 2) consists of a vent which comprises of effusive rocks. The volcanic rocks are distributed around the eastern portion of the Gowa district and cover the mountainous area in the headwaters of the Jeneberang river (Ministry of Public Works, 2005).
The rainfall in the study area is not well distributed. The average monthly rainfall ranges from $18 \mathrm{~mm}$ in August to $710 \mathrm{~mm}$ in December. High intensity rainfall usually occurs from December to March. There are two distinct seasons i.e. dry and wet. The dry season lasts from April to October with $25 \%$ of the annual rainfall. The remaining $75 \%$ of the annual rainfall occurs throughout November to March, and has its maximum during the Monsoon. Average annual rainfall is estimated at $4000 \mathrm{~mm}$. Average monthly rainfall is about $333 \mathrm{~mm}$ (Figure 3). From 1975 to 2005 the annual mean temperature, the mean daily evaporation throughout the year, the mean monthly relative humidity, and the mean monthly wind velocity were $22.8^{\circ} \mathrm{C}, 4.1 \mathrm{~mm}, 80.9 \%$ and 1.1 $\mathrm{m} / \mathrm{s}$, respectively. Evapotranspiration loss is up to $1,497 \mathrm{~mm}$ per year, that is about $50-25 \%$ of the 
annual rainfall (Ministry of Public Works, 2005).

\section{B. Methods}

In general, two types of rainfall thresholds can be established; empirical and physical thresholds (Aleotti, 2004). The empirical thresholds refer to relational values based on statistical analysis of the relationship between rainfall and landslide occurrences (Campbell, 1975; Caine, 1980; Larsen and Simon, 1993; Crozier, 1999; Guzzetti et al., 2004). Physical thresholds are usually described with the help of hydrologic and stability models that take into account different parameters such as relationships between rainfall and pore-water pressure, suction, infiltration, slope morphology, and bedrock structures (Montgomery and Dietrich, 1994; Crosta, 1998; Terlien, 1998; Crosta and Frattini, 2001; Jakob and Weatherly, 2003). Antecedent rainfall (Crozier, 1999; Rahardjo et al., 2001) also plays an important role in the determination of rainfall thresholds. Conventionally, critical precipitation indicates the amount of rainfall from the time ("zero point") in which a sharp increase in rainfall intensity is observed which is triggering off the (first) landslide (Figure 4). This increase results in a significant break in the slope of the rainfall's cumulative curve.

The empirical thresholds type was selected for this study. Records of rainfall data and history of landslide or debris flow were collected from the Ministry of Public Works of the government of Indonesia (2005) and the Hazama-Brantas, J.O (2007). No study has been conducted on the

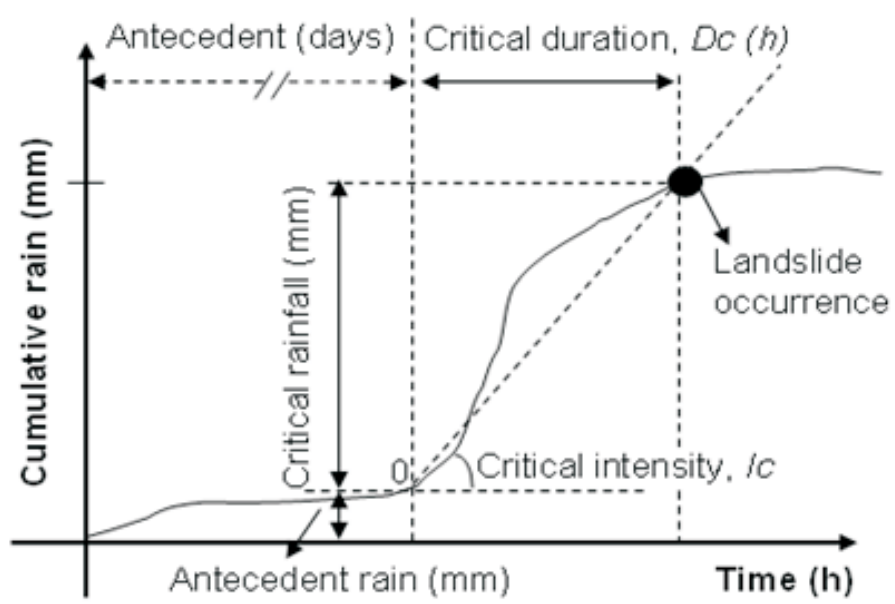

Figure 4. Rainfall parameters in relation to landslide initiation include cumulative, antecedent, intensity and duration of rainfall

Source: Aleotti (2004)

Table 2. Cases of landslides and debris flows in Mt. Bawakaraeng caldera from 1997 to 2007

\begin{tabular}{cclcll}
\hline No & \multicolumn{1}{c}{ Date } & \multicolumn{1}{c}{ Event } & No & \multicolumn{1}{c}{ Date } & \multicolumn{1}{c}{ Event } \\
\hline 1 & $23-01-1997$ & Debris flow & 12 & $09-06-2004$ & Debris flow \\
2 & $25-02-1999$ & Debris flow & 13 & $08-07-2004$ & Debris flow \\
3 & $26-01-2000$ & Debris flow & 14 & $26-01-2005$ & Debris flow \\
4 & $27-02-2001$ & Debris flow & 15 & $12-03-2005$ & Debris flow \\
5 & $25-02-2001$ & Debris flow & 16 & $17-04-2005$ & Debris flow \\
6 & $13-12-2002$ & Debris flow & 17 & $07-07-2005$ & Debris flow \\
7 & $05-03-2003$ & Debris flow & 18 & $26-11-2005$ & Debris flow \\
8 & $26-03-2004$ & Landslide & 19 & $08-02-2007$ & Landslide \\
9 & $16-04-2004$ & Debris flow & 20 & $16-02-2007$ & Debris flow \\
10 & $03-05-2004$ & Debris flow & 21 & $27-12-2007$ & Debris flow \\
11 & $07-06-2004$ & Debris flow & & & \\
\hline
\end{tabular}

Remarks: No. 1 to 7 are cases before the large scale landslide. No. 8 is the large scale landslide. No. 9 to 21 are cases after the large scale landslide. 
relationship between rainfall and landslides or debris flows before the occurrence of the large scale landslide on March 26, 2004. The existing data indicates that there is a coincidence between the times of the landslides or debris flows with the rainfall events.

We used data for twenty one cases of landslides or debris flows; rainfall intensity-duration before and after the large scale landslide on March 26, 2004 at Mt. Bawakaraeng caldera (Table 2). The reported landslides and debris flows from 1997 to 2007 were analyzed in the upper Jeneberang watershed. Empirical rainfall intensity-duration thresholds for landslides and debris flows were calculated using linear regression analysis which related rainfall intensity and the duration.

\section{RESULT AND DISCUSSION}

Twenty one cases of landslides or debris flows and rainfall intensity-duration before and after the large scale landslide in March 26, 2004 at Mt. Bawakaraeng caldera were analyzed for rainfall thresholds (Table 3). The regression equation of rainfall intensity-duration before the large scale landslide was $I=41.85 D^{-0,85}$ and the regression equation of rainfall-duration after the large scale landslide was $I=37.71 D^{-0,90}$, where $I$ is the rainfall intensity in $\mathrm{mm} / \mathrm{hr}$ and $D$ is the duration of rainfall in hr (Figure 5 and 6). Particularly, the critical intensity $(I c)$ and the critical duration $(D c)$ are parameters, which indicate the amount of rainfall and time that trigger the landslide or the

Table 3. Cases of landslides-debris flows and rainfall duration-intensity in Mt. Bawakaraeng caldera from 1997 to 2007

\begin{tabular}{cccccccc}
\hline No & Date & $\begin{array}{c}\text { Duration } \\
(\mathrm{D}, \mathrm{hr})\end{array}$ & $\begin{array}{c}\text { Intensity } \\
(\mathrm{I}, \mathrm{mm} / \mathrm{hr})\end{array}$ & No & Date & $\begin{array}{c}\text { Duration } \\
(\mathrm{D}, \mathrm{hr})\end{array}$ & $\begin{array}{c}\text { Intensity } \\
(\mathrm{I}, \mathrm{mm} / \mathrm{hr})\end{array}$ \\
\hline 1 & $23-01-1997$ & 4 & 16.8 & 12 & $09-06-2004$ & 10 & 5.0 \\
2 & $25-02-1999$ & 6 & 7.0 & 13 & $08-07-2004$ & 1 & 41.0 \\
3 & $26-01-2000$ & 90 & 1.1 & 14 & $26-01-2005$ & 7 & 11.7 \\
4 & $27-02-2001$ & 120 & 0.8 & 15 & $12-03-2005$ & 6 & 15.0 \\
5 & $25-02-2001$ & 50 & 2.0 & 16 & $17-04-2005$ & 5 & 8.5 \\
6 & $13-12-2002$ & 6 & 7.0 & 17 & $07-07-2005$ & 150 & 0.4 \\
7 & $05-03-2003$ & 8 & 7.0 & 18 & $26-11-2005$ & 70 & 1.0 \\
8 & $26-03-2004$ & 350 & 0.2 & 19 & $08-02-2007$ & 250 & 0.3 \\
9 & $16-04-2004$ & 6 & 15.0 & 20 & $16-02-2007$ & 3 & 20 \\
10 & $03-05-2004$ & 350 & 0.2 & 21 & $27-12-2007$ & 57 & 7.5 \\
11 & $07-06-2004$ & 6 & 7.3 & & & & \\
\hline
\end{tabular}

Remarks: No. 1 to 7 are cases before the large scale landslide. No. 8 is the case when the large scale landslide occurred. No. 9 to 21 are cases after the large scale landslide. No. 20 and 21 were large scale debris flows with volumes of about 7.8 million $\mathrm{m}^{3}$, and 7.0 million $\mathrm{m}^{3}$ respectively.

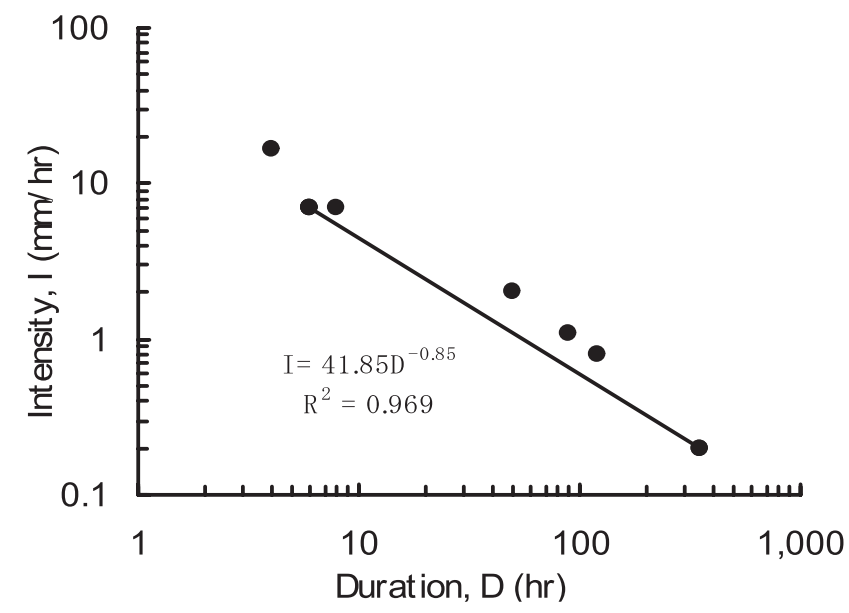

Figure 5. Rainfall intensity-duration threshold curve for landslide in the Mt. Bawakaraengcaldera, Indonesia. This is the threshold before the large scale landslide on March 26, 2004 (Table 2, No 1 to 8$)$ 


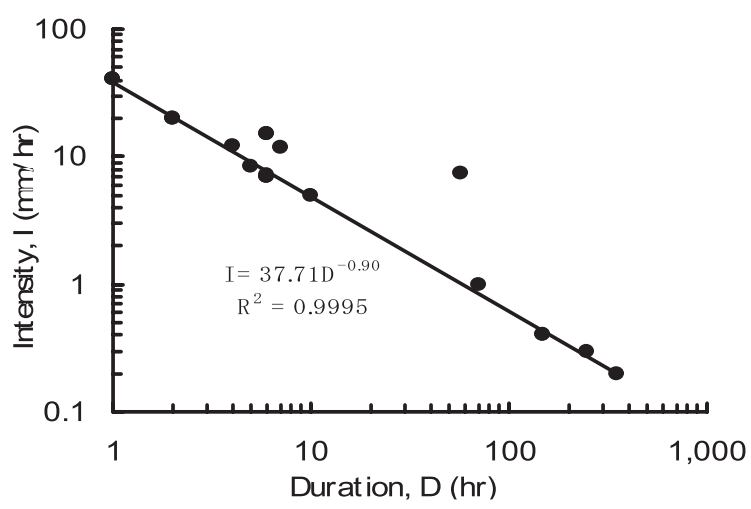

Figure 6. Rainfall intensity-duration threshold curve for landslide in the Mt. Bawakaraeng caldera, Indonesia

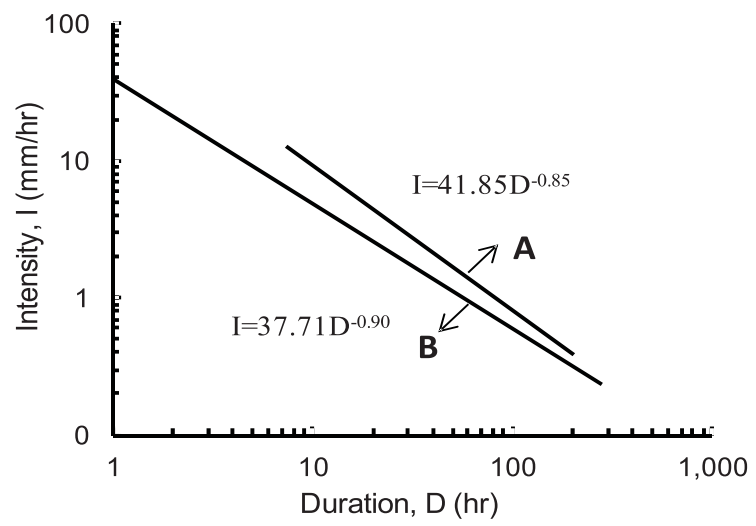

Figure 7. "A" indicates the threshold before and "B" indicates the threshold after the large scale landslide

debris flow. The regression analysis shows that rainfall intensity increases exponentially as the duration decreases. According to empirical threshold analysis, the regression curve can be considered as a reliable rainfall intensity-duration threshold for the study area, above which, landslide or debris flow events may occur. However the regression value of rainfall intensityduration before a large scale landslide was higher than after the landslide (Figure 7). After the large scale landslide in Mt. Bawakaraeng caldera, the geomorphology of the caldera has changed. The caldera has become more susceptible to debris flows and landslides due to less intense rainfall as compared to the case prior to the large scale landslide.

This is the threshold after the large scale landslide on March 26, 2004 (Table 2, No 9 to 21).

Compared to the global threshold (Crosta and Frattini, 2001), the Mt. Bawakaraeng caldera needs high intensity rainfall for landslides to occur, but when compared to the Himalaya threshold (Dahal and Hasegawa, 2008), the Mt. Bawakaraeng caldera needs lower intensity rainfall for landslides to occur (Table 4 and Figure 8).

The susceptibility of the area for the occurrence of landslides or debris flows before and after the large scale landslide was quite different (Figure 6,7 and 8). The number of cases especially of debris flows appeared more after the large scale landslide on March 26, 2004 than before the landslide. Therefore, the warning from this study will operate more effectively if it is used for the standard rainfall for the warning after the large scale landslide on March 26, 2004.

Currently, to reduce the subsequent landslides or debris flows in the study area, a pilot project under the cooperation of Japanese and Indonesian goverment have been conducted for hazard mitigation. For debris basins surrounded by residential developments, the capability to remove material may be on a 24-hours basis during storms. Also seven Sabo Dams were constructed in the Mt. Bawakaraeng caldera area. 
Table 4.Some examples of rainfall-duration threshold equations for global, regional and local scales

\begin{tabular}{|c|c|c|c|c|c|}
\hline Researches & Area & \multicolumn{4}{|c|}{ Equation } \\
\hline 1. Caine (1980) & World & $I$ & $14.82 D^{0.39}$ & & \\
\hline 2. Cancelli and Nova (1985) & Valtellina,northern Italy & I & $44.67 D^{0.78}$ & & \\
\hline 3. Ceriani et al.(1992) & North Italy & I & $20.10 D^{0.55}$ & & \\
\hline 4. Larsen and Simon(1993) & Porte Rico, Caribbean Sea & $I$ & $91.46 D^{82}$ & & \\
\hline 5. Wieczorek (1987) & California & $I$ & $1.79 D^{1}$ & & \\
\hline 6. Crosta and Frattini (2001) & World & $I$ & $0.48 \quad 7.2 D^{1}$ & & \\
\hline 7. Aleotti (2004) & Piedmont region, Italy & $I$ & $19 D^{0.50}$ & & \\
\hline 8. Dahal and Hasegawa (2008) & Himalaya, Nepal & $I$ & $73.90 D^{0.79}$ & & \\
\hline 9. Present study & Mt. Bawakaraeng & I & $41.85 D^{0.85}(A)$ & I & $37.71 D^{0.90}(B)$ \\
\hline
\end{tabular}

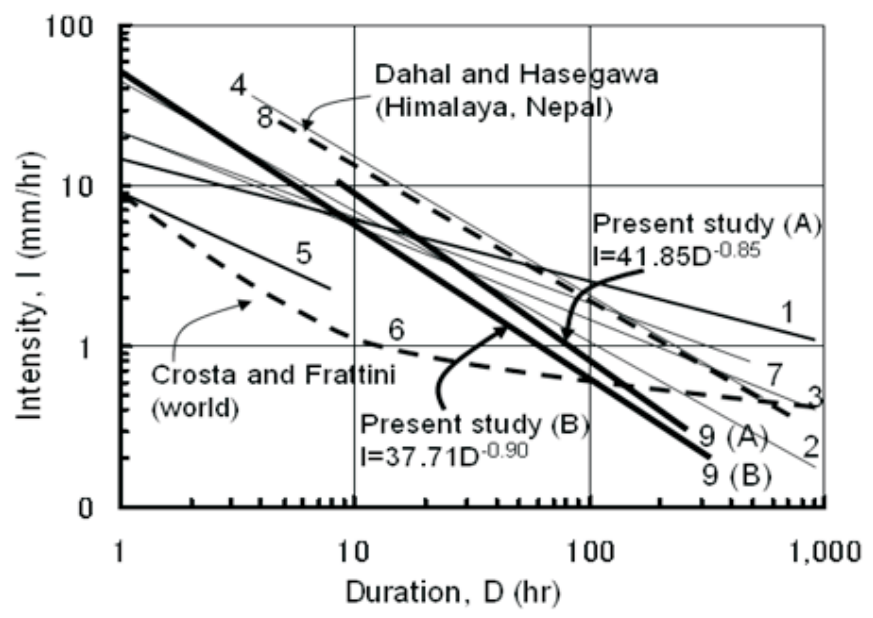

Figure 8. Comparison of the landslide-triggering rainfall intensity-duration thresholds from various studies with the present study before (A) and after (B) the large scale landslide on March 26, 2004

\section{CONCLUSION}

The present study shows that the susceptibility of the area for the occurrence of landslides or debris flows before and after the large scale landslide (March 26, 2004) was quite different. The regression value of rainfall intensity-duration before a large scale landslide was higher than after the large scale landslide. Therefore, the rainfall warning will be more effective if the rainfall warning threshold after the large scale landslide is used. The regression curve can be considered as a reliable rainfall intensity-duration threshold for the study area, above which, landslide or debris flow events may occur.

\section{REFERENCES}

Aleotti, P. 2004. A warning system of rainfallinduced shallow failure, Engineering Geology, 73: 247-265.

Caine, N. 1980. The rainfall intensity-duration control of shallow landslides and debris flows, Geografiska Annaler, 62A: 23-27.

Campbell, R.H. 1975. Soil slips, debris flows, and rainstorms in the Santa Monica Mountains and vicinity, Southern California. U.S., Professional Paper Geological Survey, 851: 1-20.

Cancelli, A. and R. Nova. 1985. Landslides in soil debris cover triggered by rainstorms in 
Valtellina (Central Alps - Italy), Proc. IV international conference and field workshop on landslides, Tokyo, August 1985, p. 267-272.

Cannon, S.H. and S.D. Ellen. 1985. Rainfall conditions for abundant debris avalanches, San Francisco Bay region, California. Geology, 38: 267-272.

Ceriani, M., S. Lauzi and N. Padovan. 1992. Rainfall and landslides in the Alpine area of Lombardia Region, central Alps, Italy, Proceedings, Interpraevent Int. Symp, Bern, Vol.2, p.9-20.

Cotecchia, V. 1978. Systematic reconnaissance mapping and registration of slope movements, Bulletin of the International Association of Engineering Geology. 17: 5-37.

Crosta, G. 1998. Regionalization of rainfall threshold: an aid to landslide hazard evaluation, Environmental Geology. 35: 131 145.

Crosta, G. and P. Frattini. 2001. Rainfall thresholds for triggering soil slips and debris flow, Proc. of EGS $2^{\text {nd }}$ Plinius Conference 2000, Mediterranean Storms, Siena, p. 463-488.

Crozier, M.J. 1997. The climate-landslide couple: a southern hemisphere perspective. In: Matthews, J.A., Brunsden, D., Frenzel, B., Glaeser, B., Weiss, M.M. (Eds.), Rapid mass movement as a source of climatic evidence for the Holocene. Gustav Fischer Verlag, Stuttgart, p. 333-354.

Crozier, M.J. 1999. Prediction of rainfall-triggered landslides: a test of the antecedent water status model, Earth Surface Processes and Landforms. 24: 825-833.

Dahal, R.K. and S. Hasegawa. 2008. Representative rainfall thresholds for landslides in the Nepal Himalaya, Geomorphology. 100: 429-443.

FAO. 2001. World Soil Resources Reports, Food and Agriculture Organization of the United Nations, Rome.

Giannecchini, R. 2006. Relationship between rainfall and shallow landslides in the southern Apuan Alps (Italy), Natural
Hazards of Earth System Science. 6: 357-364.

Glade, T., M. Crozier and P.Smith. 2000. Applying probability determination to refine landslide-triggering rainfall thresholds using an empirical Antecedent Daily Rainfall Model, Pure and Applied Geophysics. 157: 1059-1079.

Guzzetti, F., M. Cardinali, P. Reichenbach, F. Cipolla, C.Sebastiani, M. Galli and P.Salvati. 2004. Landslides triggered by the 23 November 2000 rainfall event in the Imperia Province, Western Liguria, Italy, Engineering Geology.73: 229-245.

Hasnawir and T. Kubota. 2009. Analysis for early warning of sediment-related disaster in Mt. Bawakaraeng caldera, South Sulawesi, Indonesia, Journal of the Japan Society of Erosion ControlEngineering, 62 (4): 38 - 45, 11.

Hazama-Brantas J.O. 2007. Bawakaraeng urgent sediment control project, flood report on February 16, 2007.

Hiura, H., M. Kaibori, A.Suemine, S. Yokoyama and M. Murai. 2005. Sediment related disasters generated by typhoons in 2004. In: Senneset, K., Flaate, K., Larsen, J.O. (Eds.), Landslides and Avalanches ICFL 2005 Norway, p.157-163.

Hong, Y., H. Hiura, K. Shino, K. Sassa, A. Suemine, H. Fukuoka and G.Wang. 2005. The influence of intense rainfall on the activity of large-scale crystalline schist landslides in Shikoku Island, Japan, Landslides, Vol. 2, p.97-105.

Jakob, M. and H. Weatherly. 2003. A hydroclimatic threshold for landslide initiation on the North Shore Mountains of Vancouver, British Columbia, Geomorphology. 54: $137-$ 156.

Kim, S.K., Hong, W.P. and Y.M. Kim. 1991. Prediction of rainfall triggered landslides in Korea. In: Landslides (Bell, D.H. Ed.), Rotterdam: A.A, Balkema, Vol.2, p. 989-994.

Larsen, M.C. and A. Simon.1993. A rainfall intensity-duration threshold for landslides in a humid-tropical environment, Puerto Rico, Geografiska Annaler. 75: 13-23. 
Li, T. and S. Wang. 1992. Landslide Hazards and Their Mitigation in China, Science Press, Beijing, $84 \mathrm{p}$.

Ministry of Public Works-Indonesia. 2005. Report on urgent survey for consulting engineering services of Bawakaraeng urgent sediment control project the most urgent components.

Montgomery, D.R. and W.E. Dietrich. 1994. A physically based model for the topographic control on shallow landsliding, Water Resources Research.30: 1153-1171.

Neary, D.G. and L.W. Swift Jr. 1987. Rainfall thresholds for triggering a debris avalanching event in the southern Appalachian Mountains, In: Costa, J.E., Wieczorek GF (ed) Debris flow, avalanches: process, recognition, and mitigation, GeolSoc Am Rev Engineering Geology, Vol.7, p.81-92.

Pomeroy, J.S. 1984. Storm-induced slope movements at East Brady, northwestern Pennsylvania.U.S, Geological Survey Bulletin, No.1618, 16 p.

Rahardjo, H., X.W. Li, D.G. Toll and E.C. Leong. 2001. The effect of antecedent rainfall on slope stability, Geotechnical and Geological Engineering.19:371-399.

Sukamto, R. and S. Supriatna. 1982. Geological Map of the Ujung Pandang, Bantaeng and Sinjai Quadrangles, Sulawesi.Geological Research and Development Centre, Bandung, Indonesia.

Terlien, M.T.J. 1998. The determination of statistical and deterministic hydrological landslide-triggering thresholds, Environmental Geology. 35: 124-130.

Tsuchiya, S., S. Koga, K. Sasahara, M. Matsui, M. Nakahiro, F. Watanabe, H. Shima and K. Yoshida 2004. Reconnaissance of the gigantic landslide occurred on $\mathrm{Mt}$. Bawakaraeng in the south Sulawesi state of
Indonesia and unstable debris sedimentation (prompt report), Journal of the Japan Society of Erosion Control Engineering. 57 (3): 40-46.

Wieczorek, G.F. 1987. Effect of rainfall intensity and duration on debris flows in central Santa Cruz Mountains, California. In: Crosta, G.,Wieczorek, G.F. (Eds.), Debris Flows/Avalanches: Processes, Recognition and Mitigation, Geological Society of America, Reviews in Engineering Geology. 7: 93-104.

Wieczorek, G.F. 1996. Landslide triggering mechanisms. In: Turner, A.K., Schuster, R.L. (Eds.), Landslides: Investigation and Mitigation, Transportation Research Board, Special Report 247. National Research Council, Washington, p.76-79.

Wieczorek, G.F., B.A. Morgan and R.H. Campbell. 2000. Debris flow hazards in the Blue Ridge of Central Virginia, Environmental and Engineering Geoscience. 6: 3-23.

Wilson, R.C. and G.F. Wieczorek. 1995. Rainfall threshold for the initiation of debris flow at La Honda, California, Environmental and Engineering Geoscience. 11:11-27.

Wilson, R.C., J.D. Torikai and S.D. Ellen. 1992. Development of rainfall warning thresholds for debris flows in the Honolulu District, Oahu. USGS, Open-File 92-521, $45 \mathrm{p}$.

Yano, K. 1990. Studies on deciding rainfall threshold from warning and evacuating from debris flow disaster by improving the decision method of preceding rainfall. Journal of Japan Erosion Control Society. 43 (4): 3-13 (in Japanese with English abstract).

Yatabe, R., N. Yagi and M. Enoki. 1986. Prediction of slope failure based on the amount of rainfall, Japanese Society of Civil Engineers. 376: 297-305 (in Japanese). 